\title{
PROGNOSIS OF THE DEVELOPMENT OF ORTHOSTATIC HYPOTENSION IN YOUNG MALES WITH HYPERTENSION
}

\author{
Oleksandr Bilovol', Iryna Kniazkoval, Maryna Bogun² \\ IDepartment of Clinical Pharmacology, Kharkiv National Medical University, Kharkiv, Ukraine \\ ${ }^{2}$ Foreign Languages Department, Kharkiv National Medical University, Kharkiv, Ukraine
}

\section{PROGNOZA RAZVOJA ORTOSTATSKE HIPOTENZIJE KOD MLADIH MUŠKARACA SA HIPERTENZIJOM}

\author{
Aleksandar Bilovol', Irina Knjiezkoval, Marina Bogun² \\ ${ }^{1}$ Katedra za kliničku farmakologiju, Harkovski nacionalni medicinski univerzitet, Harkov, Ukrajina \\ ${ }^{2}$ Katedra za strane jezike, Harkovski nacionalni medicinski univerzitet, Harkov, Ukrajina
}

\section{ABSTRACT}

Objective. The aim of the study was to improve the prognosis of orthostatic hypotension $(\mathrm{OH})$ in young males with hypertension $(A H)$ during antihypertensive therapy.

Methods. Total of 62 male patients were examined, mean age $31.5 \pm 3.6$ years with AH of the $1^{\text {st }}$ and $2^{\text {nd }}$ degrees. The control group consisted of 20 practically healthy persons (mean age $31.0 \pm 3.7$ years). All patients underwent general clinical examination, measurement of office blood pressure $(B P)$, daily monitoring of BP with the help of the ABPM-02 device (Meditech, Hungary), active orthostatic test (AOT) with determination of the Kerdo vegetative index (KI). During AOT, ECG and heart rate variability (HRV) were monitored according to the conventional methodology using monitors CardioTens-01 ("Meditech", Hungary). All patients underwent antihypertensive therapy. In $80.6 \%$ of patients, AH was controlled with drugs.

Results. The incidence of $\mathrm{OH}$ in patients with AH was $17.7 \%$ and did not differ significantly from the control group - $15 \%$. The patients with AH showed a decrease of the degree of parasympathetic effect according to KI data, while in the control group KI became positive. It was found that at the baseline, in the subgroup of young males with $\mathrm{AH}$ and $\mathrm{OH}$ in the orthostatic test, the spectral indices of HRV (LF and total power of the spectrum) were significantly lower than in patients with AH and negative orthostatic trial. Analysis of the dynamics of the HRV spectral indices during AOT showed that no significant changes were detected in the subgroup of patients with $\mathrm{AH}$ and $\mathrm{OH}$. Therefore, in the course of AOT, the absence of changes in HRV parameters in patients with AH confirms the presence of autonomic dysfunction and dysfunction of the autonomic supply, and also allows to predict the development of $\mathrm{OH}$.

Conclusion. Thus, prognosis of the development of $\mathrm{OH}$ in case of AH in young patients will allow more effective correction of BP in the specified cohort of patients.

Key words: hypertension; hypotension, orthostatic, predictive value of tests; therapeutics; antihypertensive agents

\section{SAŽETAK}

Cilj. Cilj studije bio je da se proceni poboljšanje prognoze ortostatske hipotenzije (OH) kod mladih muškaraca sa hipertenzijom (AH) tokom antihipertenzivne terapije.

Metode. Ispitana su 62 pacijenta muškog pola, prosečne starosti 31,5 \pm 3,6 godina sa AH I i II stepena. Kontrolnu grupu činilo je 20 praktično zdravih osoba (prosečna starost 31,0 \pm 3,7 godina). Svi pacijenti su podvrgnuti opštem kliničkom pregledu, merenju ambulantnog krvnog pritiska (BP), svakodnevnom praćenju BP pomoću uređaja ABPM-02 (,,Meditek“, Mađarska), aktivnom ortostatskom testu (AOT) uz određivanje Kerdo vegetativnog indeksa (KI). Tokom AOT-a, EKG i varijabilnost srčane frekvencije (HRV) praceni su u skladu sa konvencionalnom metodologijom koristeci monitore CardioTens-01 (,,Meditek“, Mađarska). Svi pacijenti su podvrgnuti antihipertenzivnoj terapiji. Kod 80,6\% bolesnika AH je kontrolisan lekovima.

Rezultati. Učestalost OH kod pacijenata sa AH iznosila je $17,7 \%$ i nije se značajno razlikovala od $15 \%$ kod kontrolne grupe. Pacijenti sa AH pokazali su pad stepena parasimpatičkog efekta prema podacima KI, dok je u kontrolnoj grupi KI postao pozitivan. Utvrđeno je da su u podgrupi mladih muškaraca sa AH i OH u ortostatskom testu spektralni indeksi HRV-a (LF i ukupna snaga spektra) bili znatno niži nego kod pacijenata sa AH i negativnim ortostatskim ispitivanjima. Analiza dinamike spektralnih indeksa HRV tokom AOT pokazala je da nisu utvrđene značajne promene u podgrupi pacijenata sa AH i OH. Zbog toga, tokom AOT, odsustvo promena parametara HRV kod pacijenata sa AH potvrđuje prisustvo autonomne disfunkcije i disfunkcije autonomnog snabdevanja, a takođe omogućava predviđanje razvoja $\mathrm{OH}$.

Zaključak. Prognoza razvoja OH u slučaju AH kod mladih pacijenata omoguciće efikasniju korekciju BP $u$ određenoj grupi pacijenata.

Ključne reči: hipertenzija; hipotenzija, ortostatska; prediktivna vrednost testova; terapija; antihipertenzivi 


\section{INTRODUCTION}

Arterial hypertension (AH) is one of the major health problems, due to its high prevalence and the fact that this condition is one of the main risk factors for cardiovascular diseases and their complications, disability and mortality (1). The results of clinical studies indicate that the probability of cardiovascular complications increases not only at high but also at low blood pressure values (BP) (2). One of the most common forms of transient hypotension is orthostatic hypotension $(\mathrm{OH})$, which is defined as an excessive reduction of systolic (SBP) and / or diastolic (DBP) blood pressure after the shift to orthostasis (3). The prevalence of $\mathrm{OH}$ in the population makes a total of $5 \%$ and increases up to $30 \%$ together with increasing age (4). In young males without $\mathrm{AH}$, the incidence of syncope conditions associated with $\mathrm{OH}$ makes $4-10 \%$ (5).

Orthostatic hypotension is often found in patients with $\mathrm{AH}$. Thus, the prevalence of $\mathrm{OH}$ in elderly $\mathrm{AH}$ patients is $15-35 \%(6)$. At the same time, $\mathrm{OH}$ is associated with a significant increase of the risk of cardiovascular complications, including fatal ones, and holds down its prognostic value even after correction of the main risk factors (7). Drug-induced decrease of BP is considered one of the main causes of $\mathrm{OH}$ in case of $\mathrm{AH}$, especially during administration of combination antihypertensive therapy, as well as the interaction with other drugs (8). It is known that the prognosis of $\mathrm{OH}$ in young patients with $\mathrm{AH}$ is a complex problem, often with unsatisfactory results, that preconditions the urgency of searching for new, effective diagnostic criteria and tests for this pathology. In view of the above, the aim of the study was to improve the prognosis of $\mathrm{OH}$ in young males with arterial hypertension on the background of antihypertensive therapy.

\section{PATIENTS AND METHODS}

The study includes 62 male patients, at the age of 18 35 years with $\mathrm{AH}$ of the 1 st and 2 nd degrees. The diagnosis of $\mathrm{AH}$ was made on the basis of standard criteria, in accordance with the recommendations of the European Society of Hypertension and the European Society of Cardiologists (ESH/ESC, 2013). Antihypertensive therapy was administered to all patients (monotherapy or a combination of generally accepted drug classes: diuretics, beta-blockers, slow calcium channel antagonists, ACE inhibitors / AT1-angiotensin receptor antagonists in average clinical doses). Exclusion criteria were the following: secondary forms of $\mathrm{AH}$, professional athletes, patients with the $3 \mathrm{rd}$ degree of $\mathrm{AH}$, presence of angina of effort, history of myocardial infarction, previous stroke, transient ischemic attack, chronic heart failure of the IInd - IVth functional class (NYHA), chronic renal failure, diabetes, disorders of the rhythm and conduction of the heart, severe concomitant diseases (the system of external respiration, endocrine system, oncology diseases, etc.), tricyclic antidepressants. The control group consisted of 20 healthy males.

All examined patients underwent general clinical examination, which included surveys for the detection of risk factors for cardiovascular diseases, orthostatic symptoms (dizziness, blackouts, nausea, unsteadiness, presyncope) and syncope in the past history, physical examination, anthropomorphic measurements, measurement of office BP with determination of systolic (SBP), diastolic (DBP) BP and heart rate (HR), clinical blood test and urinalysis, biochemical blood analysis with determination of indicators of lipid metabolism, glucose, creatinine, neurologist examination. Daily blood pressure monitoring (DBPM) was performed using "ABPM-02" device ("Meditech", Hungary). The following indicators were determined: daytime, nighttime, daily average (24 hours) SBP and DBP, HR.

All examined patients underwent an active orthostatic test. The study was conducted in a room with a comfortable temperature $\left(\mathrm{t}=21^{\circ} \mathrm{C}\right)$, daylight in the morning, in fasting state, excluding previous smoking and intake of tonic drinks and drugs according to the following protocol. At baseline, after 15 minutes of rest in prone position, SBP and DBP were measured on the brachial artery with simultaneous HR count and determination of pulse pressure as a difference between SBP and DBP. Then a patient quickly moved to a standing position and remained in it for 5 minutes, after what the measurements were redone. Changes in hemodynamic parameters $(\Delta)$ were calculated as the difference between subsequent and initial values. Indicators of pulse pressure (PP) and vegetative Kerdo index (KI) were determined at baseline and after 5 minutes of orthostasis by the formula:

$$
\mathrm{KI}\left(\mathrm{RU}^{*}\right)=100 \times(1-\mathrm{DBP} / \mathrm{HR}) \text {. }
$$$$
* \text { RU- relative unit }
$$

In case of complete vegetative equilibrium in the cardiovascular system $\mathrm{KI}$ is equal to 0 . If the coefficient is positive, then sympathetic effects are predominant, if negative - parasympathetic ones. Criterion of $\mathrm{OH}$ was taken as the reduction of BPP by $20 \mathrm{~mm} \mathrm{Hg}$ or more and/or DBP for $10 \mathrm{~mm} \mathrm{Hg}$ or more from the initial data after the shift to orthostasis.

To objectify the condition of patients, orthostatic symptoms were registered according to their medical histories and during the trial. The patients included in the study had no subjective orthostatic symptoms (dizziness, blackouts, nausea, unsteadiness, presyncope) and syncope in the anamnesis. Clinical symptoms which were registered in the first seconds of orthostasis and completely disappeared within 30 seconds were considered an early $\mathrm{OH}$. In case of symptoms appearing up to 1 minute of orthostasis, these manifestations were considered as a classic $\mathrm{OH}$. 
During an active orthostatic test, electrocardiogram (ECG) and heart rate variability (HRV) indicators were monitored for all patients according to the conventional methodology using monitors CardioTens-01 («Meditech», Hungary). In the group of patients with $\mathrm{AH}$ and the control group the spectral density of low frequency power was analyzed and compared - LF in $\mathrm{ms}^{2}$, high frequencies $\mathrm{HF}$ in $\mathrm{ms}^{2}$, the ratio of the low-frequency component to the high-frequency component of the spectrum - LF / HF, and the total spectrum power - Total for 5 minutes until orthostasis and within the first five minutes after the shift to orthostasis.

Statistical processing of the study results was performed using Statistica 8.0 software for Windows (StatSoft Inc. USA). During analysis, mean values (Me) were calculated and the interquartile interval (II) was registered. Comparison of qualitative parameters was performed using Fisher's exact two-sided test, and comparison of quantitative indicators in the study groups was made using the Mann-Whitney criteria. Differences at $\mathrm{p}<0.05$ were considered statistically significant. Random value relations were evaluated using the Spearman's correlation coefficient and the multiple regression method.

\section{RESULTS}

The mean age of experimental group was $31.5 \pm 3.6$ years ( \pm standard deviation). An average duration of $\mathrm{AH}$ made $2.9 \pm 1.6$ years. In $24.2 \%$ of patients there was a hypertension of the $1^{\text {st }}$ degree, in $75.8 \%$ - the $2^{\text {nd }}$ degree. A family history of hypertension was reported in $69.4 \%$, and a family history of early cardiovascular events in $29.0 \%$ of cases. The body mass index (BMI) of the examined persons was $27.3 \pm 0.8 \mathrm{~kg} / \mathrm{m}^{2}$. Abdominal obesity was found in $25.8 \%$ of patients, dyslipidemia in $30.6 \%$ of cases, metabolic syndrome in $29.0 \%$ of patients. In $80.6 \%$ of patients, $\mathrm{AH}$ was controlled with drugs. The age in control group healthy males was $31.0 \pm 3.7$ years. Mean values of central hemodynamics at baseline and during active orthostatic tests are presented in Table 1.

It was found that in baseline conditions and during active orthostatic tests, the values of SBP, DBP and PP were significantly higher than in the group of healthy persons. On the background of active orthostatic test in young males with $\mathrm{AH}$, a decrease of $\mathrm{ABP}$ in average for $9.0 \mathrm{~mm} \mathrm{Hg}$ was found, an increase of DBP for $6.0 \mathrm{~mm} \mathrm{Hg}$, HR acceleration by 14.0 beats / min were found (Figure 1). The patients with AH differed from healthy individuals by

Table 1. Dynamics of central hemodynamics indices during active orthostatic test

\begin{tabular}{|l|l|l|l|l|}
\hline Index & Settings & Main group & Control group & $\mathrm{p}$ \\
\hline \multirow{3}{*}{ SBP, mm Hg } & Baseline & $139(130144)$ & $120(118132)$ & $<0.001$ \\
\cline { 2 - 5 } & During test & $130(124138)^{*}$ & $118(116122)$ & $<0.001$ \\
\hline \multirow{2}{*}{ DBP, mm Hg } & Baseline & $84(7888)$ & $75(7081)$ & $<0.001$ \\
\cline { 2 - 5 } & During test & $90(8494)^{*}$ & $79(7284)^{*}$ & $<0.001$ \\
\hline \multirow{2}{*}{ PP, mm Hg } & Baseline & $54(4762)$ & $46(4252)$ & $<0.001$ \\
\cline { 2 - 5 } & During test & $46(4052)^{*}$ & $43(3848)$ & 0.14 \\
\hline \multirow{2}{*}{$\begin{array}{l}\text { Kerdo index, beats / min } \\
\text { RU }\end{array}$} & Baseline & $72(6678)$ & $70(6474)$ & 0.16 \\
\cline { 2 - 5 } & During test & $86(7692)^{*}$ & $88(7692)^{*}$ & 0.5 \\
\cline { 2 - 5 } & Baseline & $-21(-7-28)$ & $-17(-6-26)$ & 0.82 \\
\hline
\end{tabular}

*accuracy of differences from baseline data $(\mathrm{p}<0.05)$

Main group

(mm HG)

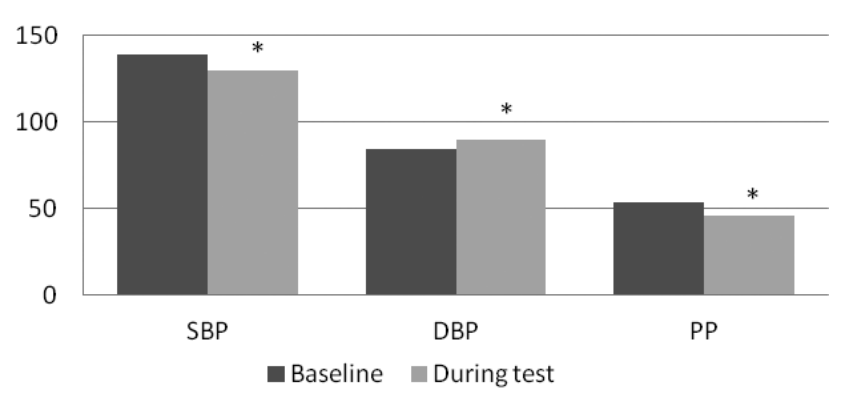

*-accurancy of differences from baseline data $(\mathrm{p}<0,05)$.
Control group

( $\mathrm{mm} \mathrm{Hg}$ )

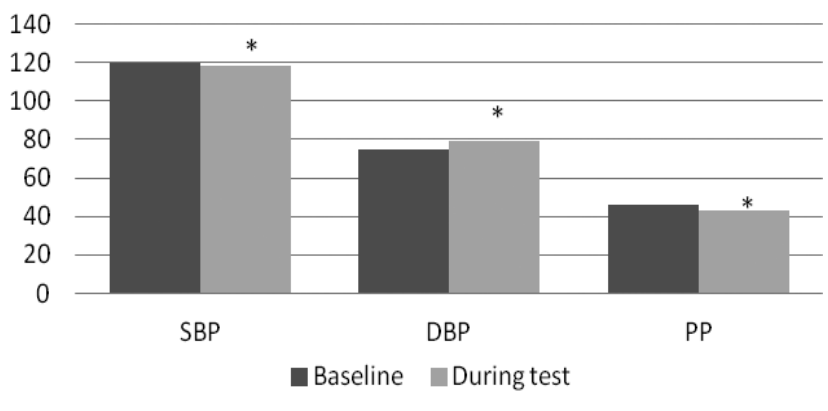

*-accurancy of differences from baseline data $(p<0,05)$.

Figure 1. Change of SBP, DBP, pulse pressure during the transition to orthostasis in the studied groups 
a less degree of HR increase on the basis of an orthostatic test. Figure 1 shows that the decrease of SBP after the transition to orthostasis occurs in both groups, but in the control group it is less in contrast to the group of patients with $\mathrm{AH}$ (A). After the transition to orthostasis, DBP increases in both groups, but in contrast to the group of $\mathrm{AH}$ patients in healthy individuals, an increase of DBP in orthostasis is less pronounced (B). In the baseline conditions evaluation of HRV in young males with $\mathrm{AH}$ and healthy individuals, according to the Kerdo index, showed prevalence of parasympathetic effect, but no significant differences between the groups were observed. However, in both groups there was a significant increase of this indicator after the shift to orthostasis.

Changes in the spectral parameters of heart rate variability during active orthostatic testing are presented in Table 2. Analysis of the spectral characteristics of HRV showed that in the baseline conditions all components of the HRV spectrum were lower than in practically healthy patients, but the LF / HF ratio between the groups did not differ. During active orthostatic testing, young patients with $\mathrm{AH}$ showed an increase in sympathetic and a decrease in the parasympathetic tone of the autonomic nervous system, an increase in the total spectrum power. However, in the control group, only the tone of the parasympathetic nervous system was decreased (Figure 2).

In the AH group, the initial spectral parameters of HRV were lower than in the control group, and the LF / HF ratio in the groups did not differ. The transition to orthostasis in patients with $\mathrm{AH}$ was accompanied by an increase of the low-frequency component (low frequency - LF) - mainly of a sympathetic effect on the heart rhythm and a decrease of the high-frequency component of the spectrum (high frequency - HF), which reflects the level of parasympathetic tone of the autonomic nervous system, an increase of the total spectrum power (Total), while in healthy individuals only a decrease of the tone of the parasympathetic nervous system was registered.

\section{DISCUSSION}

It was found that in the subgroup of $\mathrm{AH}$ patients with $\mathrm{OH}$ during an active orthostatic test, a decrease in the mean BP from 148/84 $\mathrm{mm} \mathrm{Hg}$ to $122 / 78 \mathrm{~mm} \mathrm{Hg}$, PP from 58 to $40 \mathrm{~mm} \mathrm{Hg}$, HR acceleration by 18 beats / min, an increase in the Kerdo index from -10 to -1.4 were observed. In the subgroup of healthy individuals with $\mathrm{OH}$, a decrease in mean BP from 140/80 $\mathrm{mm} \mathrm{Hg}$ to $118 / 76 \mathrm{~mm}$ $\mathrm{Hg}$, PP from 54 to $35 \mathrm{~mm} \mathrm{Hg}$, HR acceleration by 21 beats $/ \mathrm{min}$, an increase in Kerdo index from -20 to +9 were observed during active orthostatic testing. It is important to emphasize that that the patients with $\mathrm{OH}$ had no orthostatic complaints. Thus, in the subgroups of patients with $\mathrm{AH}$ and healthy persons with an extreme decrease in BP during active orthostatic testing, the degree of reduction of SBP and DBP and the HR acceleration were

Table 2. Dynamics of parameters of heart rate variability during active orthostatic test.

\begin{tabular}{|l|l|l|l|l|}
\hline Index & Settings & Main group & Control group & p \\
\hline \multirow{2}{*}{ LF, $\mathrm{ms}^{2}$} & Baseline & $306(162674)$ & $618(2371008)$ & 0.012 \\
\cline { 2 - 5 } & During test & $334(193641)^{*}$ & $573(3761025)$ & 0.01 \\
\hline \multirow{2}{*}{$\mathrm{HF}, \mathrm{ms}^{2}$} & Baseline & $175(77319)$ & $294(144563)$ & 0.014 \\
\cline { 2 - 5 } & During test & $82(40145)^{*}$ & $91(75250)^{*}$ & 0.21 \\
\hline \multirow{2}{*}{ LF/HF, RU } & Baseline & $2.1(1.52 .9)$ & $2,2(1,23,1)$ & 0.5 \\
\cline { 2 - 5 } & During test & $3.9(2.96 .2)$ & $5.9(3.87 .4)^{*}$ & 0.13 \\
\hline \multirow{2}{*}{ Total, $\mathrm{ms}^{2}$} & Baseline & $1058(5682297)$ & $2010(10263148)$ & 0.02 \\
\cline { 2 - 5 } & During test & $1565(6733479)$ & $2263(9913892)$ & 0.13 \\
\hline
\end{tabular}

*accuracy of differences from baseline data $(\mathrm{p}<0.05)$

Main group

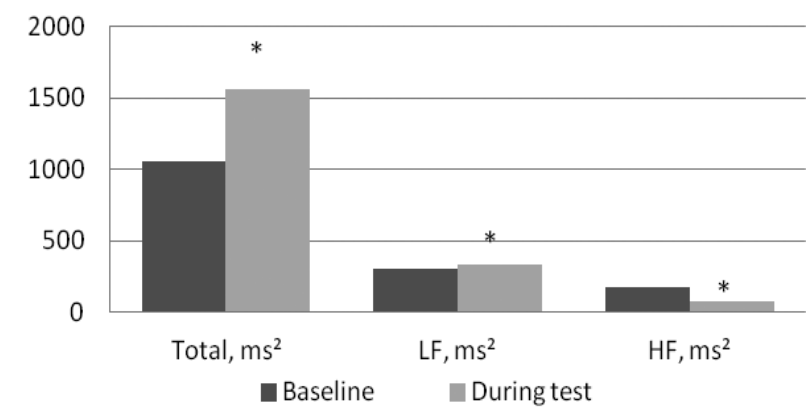

*-accurancy of differences from baseline data $(p<0,05)$.
Control group

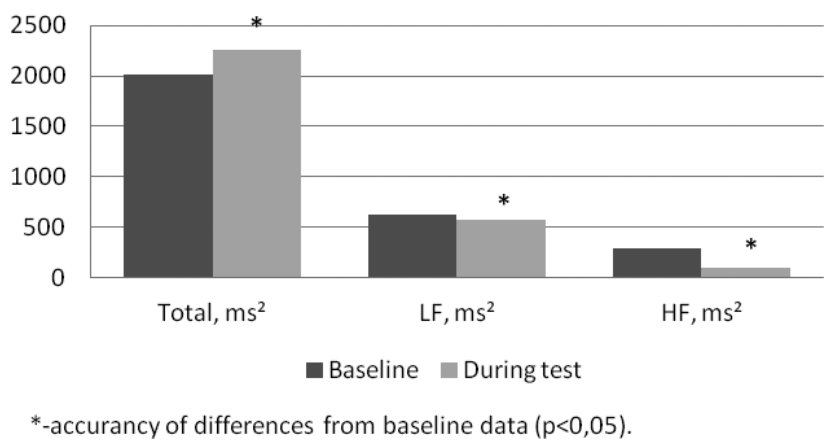

Figure 2. Changes of the spectral characteristics of HRV during the transition to orthostasis in the studied groups. 
not significantly different. However, in patients with $\mathrm{AH}$ there was a decrease in the degree of parasympathetic effect according to Kerdo index data, whereas in healthy persons Kerdo index became positive, indicating an activation of sympathetic tone.

During active orthostatic testing, the incidence of $\mathrm{OH}$ in patients with $\mathrm{AH}$ was found in $17.7 \%$ (11 persons) and did not differ significantly from the figures of almost healthy persons - $15 \%$ ( 3 persons). Our data differs from the results of other clinical studies, according to which the prevalence of $\mathrm{OH}$ in patients with $\mathrm{AH}$ was $13.4 \%$ and was higher than in healthy persons $5.5 \%$ (9). Obviously, this difference may be caused by the young age of the patients with $\mathrm{AH}$ in our study. At the same time, in elderly patients with $\mathrm{AH}$, the probability of the development of orthostatic reactions of $\mathrm{BP}$ may increase due to the progressive vessels remodeling and an increase of baroreflex insufficiency (10). Thus, the same incidence of $\mathrm{OH}$ development in patients with $\mathrm{AH}$ and healthy individuals may be a specific feature of the response of young patients with controlled $\mathrm{AH}$ to extensive orthostasis.

It should be noted that the mechanisms of development of $\mathrm{OH}$ in case of $\mathrm{AH}$ in young and practically healthy persons are different. It was found that in patients with $\mathrm{AH}$ a significant contribution is made by heart and vessels remodeling, as well as combination drug therapy. Therefore, when reaching the target levels of BP, the possibility of developing $\mathrm{OH}$ is not excluded, and therefore it is necessary to pay attention to the presence of orthostatic complaints in patients.

Clinical studies show that in healthy individuals, excessive activation of sympathetic and inhibition of parasympathetic effects on the cardiovascular system in the first five minutes of orthostasis are the predictors of vasovagal syncope development during tilt testing (11, 12). Therefore, in young males with AH during an active orthostatic test, the response of spectral indices of HRV was similar to the patients with vasovagal syncope, indicating the presence of vegetative imbalance in patients with $\mathrm{AH}$.

It was established that at baseline, in the subgroup of young males with $\mathrm{AH}$ and $\mathrm{OH}$ in the orthostatic test, spectral indices of HRV, namely power in the LF range and total power of the spectrum, were significantly lower than in patients with $\mathrm{AH}$ and negative orthostatic trial. Analysis of the dynamics of spectral indices of HRV during active orthostatic testing showed that no significant changes were detected in the subgroup of patients with $\mathrm{AH}$ and $\mathrm{OH}$. At the same time, the patients with $\mathrm{AH}$ and negative orthostatic trial showed pronounced activation of the sympathetic and parasympathetic tone of the autonomic nervous system. Therefore, during active orthostatic testing, the absence of changes in HRV parameters in young patients with $\mathrm{AH}$ confirms the presence of autonomic dysfunction and disturbances of the autonomic supply, and also allows to prognose the development of $\mathrm{OH}$. It has been previously noted that antihypertensive drugs, in particular ACE inhibitors, are capable of suppressive effect on the autonomic regulation of the heart (13). In the analysis of drug therapy in patients with $\mathrm{AH}$ among 11 men with $\mathrm{OH}$ on the background of active orthostatic trial in $10(90.9 \%)$ persons ACE inhibitors were included in the treatment regimens.

In the subgroup of healthy persons with positive orthostatic trial, alternatively to the patients with $\mathrm{AH}$, a significant increase in the LF / HF ratio due to the tendency to LF increase and a statistically significant HF decrease were observed. The data obtained show an increase in the activity of the sympathetic component of the autonomic nervous system and correspond to the results of the previously conducted clinical studies (14).

Thus, the prognosis of the development of orthostatic hypotension in case of arterial hypertension in young patients will allow more effective correction of blood pressure in the specified cohort of patients.

\section{REFERENCES}

1. Kotseva K, De Bacquer D, De Backer G, et al. On behalf of The Euroaspire Investigators Lifestyle and risk factor management in people at high risk of cardiovascular disease. A report from the European Society of Cardiology European Action on Secondary and Primary Prevention by Intervention to Reduce Events (EUROASPIRE) IV cross-sectional survey in 14 European regions. Eur J Prev Cardiol 2016; 23: 2007-2018.

2. Grujic V, Dragnic N, Kvrgic S, Susnjevic S, Grujic J, Travar S. Epidemiology of hypertension in Serbia: results of a national survey. J Epidemiol 2012; 22: 261-6.

3. Biaggioni I. Orthostatic hypotension in the hypertensive patient. Am J Hypertens 2018; 31: 1255-9.

4. Ali A, Ali NS, Waqas N, et al. Management of orthostatic hypotension: a literature review. Cureus 2018; 10: e3166. (doi: 10.7759/cureus.3166).

5. Thomas KN, Cotter JD, Galvin SD, Williams MJ, Willie CK, Ainslie PN. Initial orthostatic hypotension is unrelated to orthostatic tolerance in healthy young subjects. J Appl Physiol 2009; 107: 506-17.

6. Romero-Ortuno R, O'Connell MD, Finucane C, Soraghan C, Fan CW, Kenny RA. Insights into the clinical management of the syndrome of supine hypertension - orthostatic hypotension $(\mathrm{SH}-\mathrm{OH})$ : The Irish Longitudinal Study on Ageing (TILDA). BMC Geriatrics 2013; 13: 73. (doi:10.1186/1471-231813-73). 
7. Juraschek SP, Appel LJ, Miller ER, Mukamal KJ, Lipsitz LA. Hypertension treatment effects on orthostatic hypotension and its relationship with cardiovascular disease. Hypertension 2018; 72: 98693.

8. Juraschek SP, Lipsitz LA, Beach JL, Mukamal KJ. Association of orthostatic hypotension timing with clinical events in adults with diabetes and hypertension: results from the ACCORD Trial. Am J Hypertens 2019; 32: 684-94.

9. Fedorowski A, Burri P, Melander O. Orthostatic hypotension in genetically related hypertensive and normotensive individuals J Hypertens 2009; 27: 97682.

10. Bliziotis IA, Destounis A, Stergiou GS. Home vs. ambulatory and office blood pressure in predicting target organ damage in hypertension: a systematic review and meta-analysis. J Hypertens 2012; 30: 1289-99.
11. Kozluk E, Cybulski G, Piatkowska A, et al. Early hemodynamic response to the tilt test in patients with syncope. Arch Med Sci 2014; 10: 1078-85.

12. Buszko K, Kujawski S, Newton JL, Zalewski P. Hemodynamic response to the head-up tilt test in patients with syncope as a predictor of the test outcome: a meta-analysis approach . Front Physiol 2019; 10: 184. (doi: 10.3389/fphys.2019.00184. eCollection 2019).

13. Tasic D, Tasic N, Dragisic D, Mitrovic M. Orthostatic hypotension and therapy with an ace inhibitor in hypertensive patients. Ser J Exp Clin Res 2017; 18: 61-6.

14. Shibao C, Lipsitz LA, Biaggioni I. Evaluation and treatment of orthostatic hypotension. J Am Soc Hypertens 2013; 7: 317-24. 